\title{
GUS SCHRADER: AUTO RACING CHAMPION
}

Wednesday, October 22, 1941, a race at the Louisiana State Fair in Shreveport was expected to decide the national dirt track auto racing championship. Defending titleholder Gus Schrader of Cedar Rapids, Iowa, the racer who had entertained millions with his expert driving, was killed in this race. Gus had scheduled this to be his last race before retirement. The following is the story of that race and of Gus Schrader, the racer, as told by Sec Taylor, sports editor of the Des Moines Register, the following morning.

Gus Schrader, the pudgy-faced veteran of the half-mile ovals and perennial dirt track auto racing champion, will provide no more thrills.

The long and hazardous trail over which the pilot of a racing car must steer came to an end for Schrader at the Louisiana State fair at Shreveport Wednesday when he was fatally injured in an accident on the track. He died two hours later in a sanitarium there.

The accident which caused the veteran's death came when his Offenhauser Special locked wheels with a machine driven by Jimmy Wilburn. The cars spun in a cloud of dust, Schrader being catapulted from the seat of his little speedster over a fence nearly 15 feet away, landing on his head.

Wilburn, who was challenging for Schrader's national title this season, escaped uninjured, according to a dispatch by the Associated Press.

Schrader suffered a skull fracture and concussion, and died of a cerebral hemorrhage.

Wednesday's race was the last scheduled this year for Gus, who had planned to go into retirement following the event.

The race would have decided the 1941 national championship, which is awarded on points scored at fairs and other speed programs.

Schrader's wife, Eunice, was in the stands when the crash occurred, according to press dispatches. They had planned 


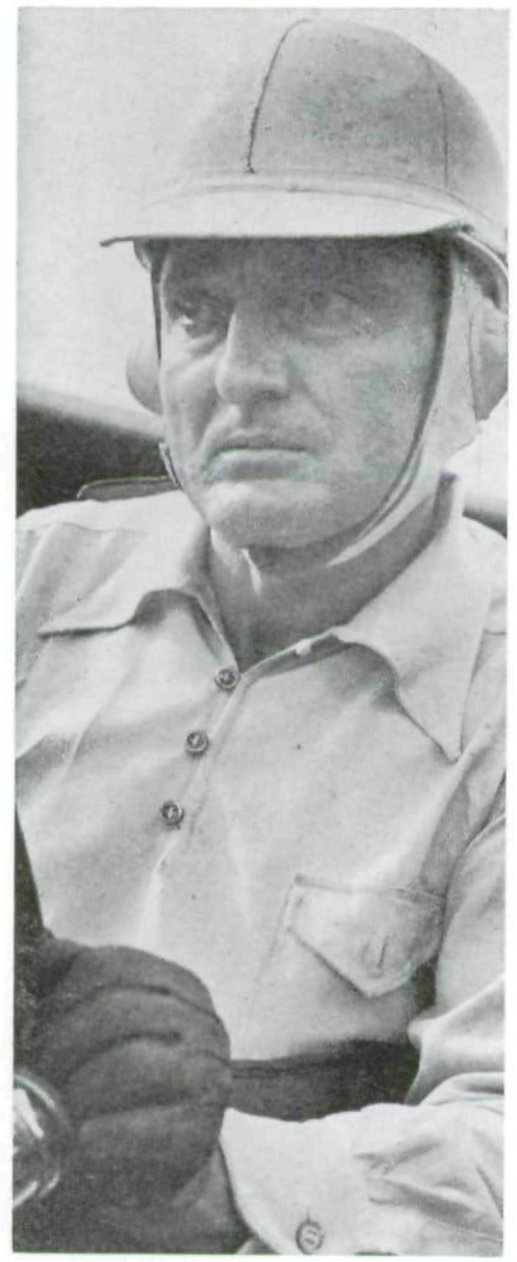

Register of Tribune Pboto

Racer Gus Schrader

to leave Shreveport today for Cedar Rapids, going from there to Winnipeg, Canada, on a hunting trip.

Schrader, who was 46 , had been talking of retiring for the past two years, and when he was here for the 1941 Iowa State Fair races, in which he competed annually, he told friends this was to be his last year of competition. 
He planned to retire to a farm which he had purchased from what he had saved from prize money in the racing game.

Compiling one of the most brilliant records in the history of auto racing, Schrader, in more than 20 years, had won an average of four of seven starts. He had driven in more than 1,100 races.

The veteran driver claimed Cedar Rapids as his home, but he usually spent each winter in Hollywood, Cal., where he personally dismantled his racer and assembled it, putting in new parts where needed and occasionally making improvements in the mechanism as experience and new inventions dictated.

Possibly no other race driver has entertained as many persons as Schrader. The annual Memorial day 500-mile race at Indianapolis, Ind., attracts more persons each year than any other race event. Schrader did not compete in it because it is run under the sanction of the American Automobile Association which had him under suspension because he competed in state and county fair races under the sanction of the International Motor Contests Association, a rival organization.

These races each year attract more spectators than all the events held under the A.A.A., including the Indianapolis event, and Schrader competed in most of them.

However, Gus did compete in one Indianapolis 500-mile test. That was in 1935 when he was forced to withdraw after 116 miles when his car developed motor trouble.

Several million persons must have thrilled to his expert handling of a car during his long and successful career. He raced each year at the Iowa State fair and various other fairs in the state and competed in 'still' dates here, at Cedar Rapids and elsewhere frequently.

In addition he raced annually or at least often at Sedalia, Mo.; Springfield, Mo.; Oklahoma City, Okla.; Shreveport, La.; Tampa, Fla.; Chattanooga, Tenn.; Birmingham, Ala.; Brockton and Springfield, Mass.; St. Paul, Minn., and many other large racing centers as well as in smaller cities.

Schrader began his racing career as a motorcycle rider. $\mathrm{He}$ was at Camp Dodge, near Des Moines, during World War I, 


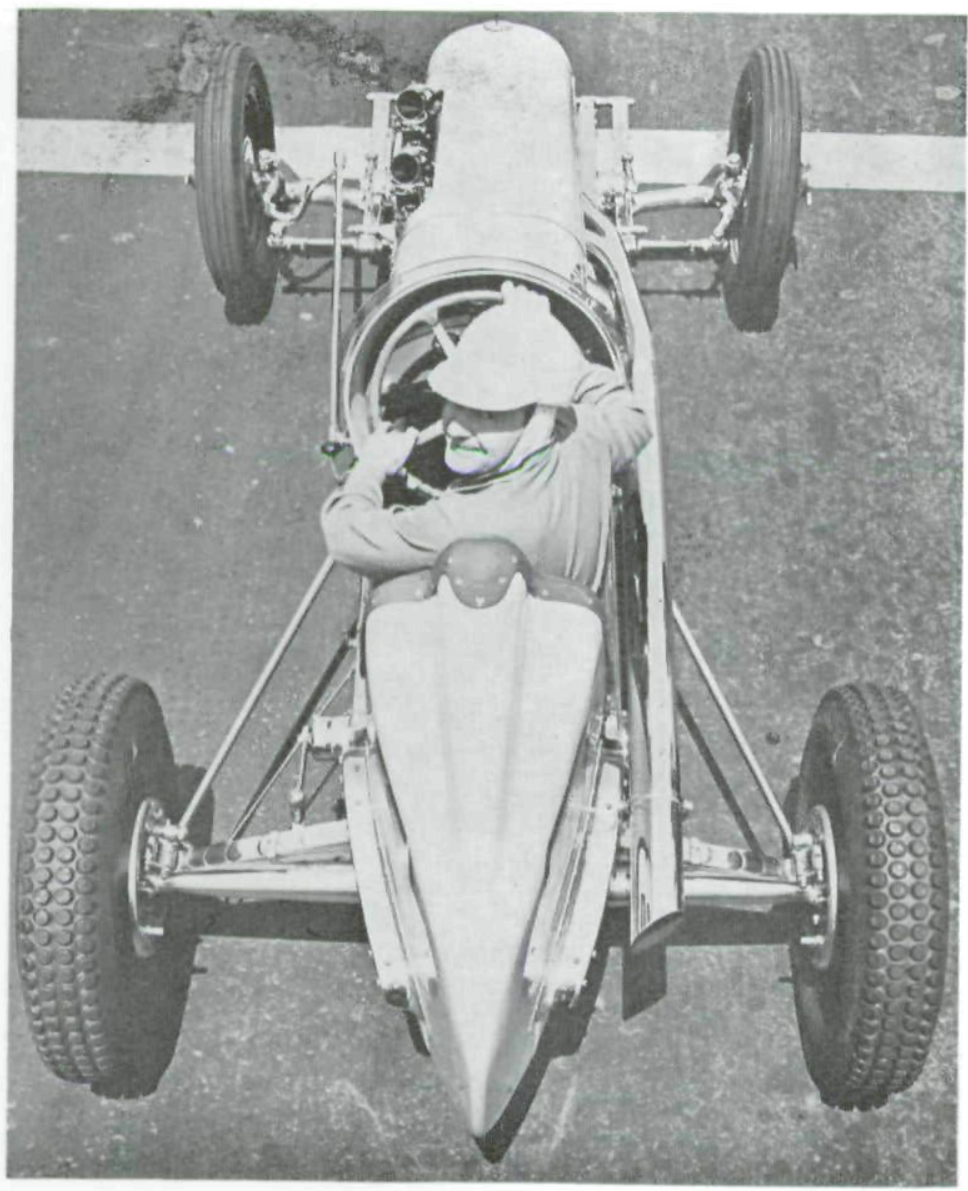

Schrader's Last Race

Register of Tribune Photo

and competed in motorcycle races whenever he could obtain leaves of absence.

He won his first national dirt track championship under I. M. C. A. auspices in 1932 and has held the title since with the exception of 1938 when Emory Collins, LeMars, Ia., with whom his career was closely linked, won it.

They were arch-rivals but good friends until two years ago. They even went on hunting and fishing trips together, both being fond of the outdoors, but their racing rivalry was so keen that at times, it is said, they did not speak to each other 
for two or three weeks at a time. But when there was no racing they would make up and become boon companions.

Two years ago Collins left the management of John Sloan, under whom Schrader has raced ever since the death of Alex Sloan, father of John, and the father of dirt track auto racing in America. Since then Collins has been handled by a rival promoter and as a consequence the two have not been seen on the track together.

Schrader probably has set more half-mile dirt track auto racing records than any pilot, including Barney Oldfield, Louis Disbrow, Sig Haugdahl, Ray Lampkin and other famous pilots. He held virtually all the half-mile records at the time of his death.

An excellent mechanic before he turned driver, Schrader drew specifications for the famous Miller motor which brought him into the national spotlight in 1934.

The motor, without magneto and carburetor, sold for $\$ 2,200$ and had 220 horsepower.

In 1933 the Miller company sold out to Offenhauser and Schrader bought two of the latter type motors, one for halfmile tracks and the other for the mile.

The veteran driver was known as a careful racer, but one who would take conservative chances when it was necessary to do so to win a race. In other words he was courageous and had the nerve necessary to make a successful pilot, but he was in no sense reckless.

During his long career he had only two serious accidents prior to Wednesday and neither came in automobile races.

In 1926, he was thrown from a motorcycle while competing at the Anamosa, Ia., fair race. In 1937, he was critically hurt in a California highway accident.

It was while convalescing in a hospital there that he met and later was married to his nurse, the present Mrs. Schrader.

Schrader was born at Newhall, Ia. Surviving him besides his wife, are three brothers, Emmett, Harry and Irving Schrader, all of Newhall, and his mother, Mrs. Mary Schrader, now of Vinton, Ia.

His father died in 1923.

Funeral arrangements were indefinite Wednesday night, but it was believed burial would be in Los Angeles, Cal. 
Copyright of Annals of Iowa is the property of State of Iowa, by \& through the State Historical Society of Iowa and its content may not be copied or emailed to multiple sites or posted to a listserv without the copyright holder's express written permission. However, users may print, download, or email articles for individual use. 